\title{
Indo-Arabian stone anchor of Manikapatna, Odisha, east coast of India: an indicator of maritime contacts of Odisha
}

\author{
Sila Tripati \\ CSIR-National Institute of Oceanography, Dona Paula, Goa 403 004, India
}

Numerous stone and iron anchors of various shapes and sizes have been brought to light during the maritime archaeological explorations along the Indian littoral. And anchors are proxies to maritime archaeological studies. The recent maritime archaeological studies along the Manikapatna Coast of Chilika Lake, Odisha, India, discovered one broken Indo-Arabian stone anchor. The archaeological excavation findings suggest that Manikapatna served as a port from the early historical period up to the 18 th century $C E$. Besides the Indo-Arabian stone anchor, composite, kellick, one-armed anchor with stone stock and single hole stone anchors were previously documented along the Odisha coast. None of the anchors were accompanied by associated findings, nor from any strata, and therefore, these anchors differ in their period and usage. Nonetheless, some of the stone anchors are still used by the fisherfolk of Odisha in their traditional crafts. The finding of the Indo-Arabian stone anchor of Manikapatna has a great significance in the maritime history of Odisha. This paper discusses the IndoArabian stone anchor found at Manikapatna coast, its importance in the maritime history of Odisha and in comparison with other Indo-Arabian types of stone anchors of the Indian subcontinent.

Keywords: Arab contacts, Chilika lake, Manikapatna, maritime contact, stone anchor.

AN anchor is a device used by every watercraft to moor the watercraft to the seabed. Initially, stone anchors were used, and in the later period anchors made of wood, lead and iron were used worldwide. Moreover, wood was also used along with lead and iron in making anchors. In earlier times boatmen either lowered or dropped the anchors by tying a rope to them which held the ground of sea, river or lake firmly. Throughout the world, various types and sizes of anchors have been documented and studied. Stone anchors are still in use along the Indian coast despite several advancements made in shipping. Except for some coastal regions, stone anchors of different types have been recorded all along the Indian coast ${ }^{1}$. Among the stone anchors, an abundant number of them

e-mail: sila@nio.org recovered along the Indian coast belonged to the IndoArabian variety followed by composite and other types (Table 1). In an archaeological context, the Harappans were the earliest users of stone anchors in the Indian subcontinent ${ }^{2}$, which were recorded from the excavations of Lothal and Kuntasi, both Harappan sites located along the Gujarat coast. These anchors are made of sandstone; differ entirely in their shape, size, nature of rope holes, including the working capabilities. Although these have been accounted as anchors ${ }^{3-5}$, it is difficult to understand how these were used and their context of finding and function. In view of the above, it is highly essential to study the stone anchors of Lothal and Kuntasi more carefully before drawing any further conclusions.

\section{Manikapatna as a port and stone anchors of Odisha}

The maritime history of Odisha, India, on the eastern littoral goes back to 8th-6th century BCE, if not earlier. Manikapatna, which lies on the bank of Chilika Lake, in Brahmagiri taluk of Puri district, Odisha, served as a port from the early historical period to the medieval period. Chilika, the biggest brackish water inshore lake connected to the Bay of Bengal through a narrow mouth, has also played a significant role in the maritime history of Odisha. Several regional literatures including the Brahmanda Purana (10th century CE), mentioned about the maritime activities of Chilika and even in ancient times, ships sailed from Chilika to Bali, Java, Malaya, Ceylon and other countries ${ }^{6,7}$. In the Chilika Yatra, Chintamani Mohanty has referred to ships sailing to overseas countries which carried stones tied with rope and lowered to anchor the boats even in the lake in the case of storms and cyclones. Probably Mohanty referred to stone anchors (langars). Even ships in Chilika Lake used heavy and perforated stones as anchors ${ }^{8}$.

Several ports and trade centres existed along the bank and adjoining region of Chilika, among which Manikapatna was notable (Figure 1). Importance of Manikapatna as a port was unknown before 1989. The Odishan Institute of Maritime and Southeast Asian Studies (OIMSEAS), Bhubaneswar, undertook excavations between 1989 and 
Table 1. Stone anchor found sites in India

\begin{tabular}{|c|c|c|c|c|c|c|}
\hline Name of the site & $\begin{array}{c}\text { Composite } \\
\text { anchor }\end{array}$ & $\begin{array}{l}\text { Indo-Arabian } \\
\text { anchor }\end{array}$ & $\begin{array}{l}\text { Ring stone } \\
\text { anchor }\end{array}$ & $\begin{array}{l}\text { Single hole } \\
\text { anchor }\end{array}$ & $\begin{array}{l}\text { Kellick } \\
\text { anchor }\end{array}$ & Total \\
\hline \multicolumn{7}{|l|}{ West coast } \\
\hline \multicolumn{7}{|l|}{ Gujarat } \\
\hline Gulf of Kachchh & - & 1 & - & - & - & 1 \\
\hline Bet Dwarka & 13 & 7 & 1 & - & - & 21 \\
\hline Aramda & 1 & 1 & - & - & - & 2 \\
\hline Dwarka & 35 & 63 & 24 & 1 & - & 123 \\
\hline Miyani & 2 & 6 & 4 & - & - & 12 \\
\hline Visawada & 10 & 2 & 1 & 1 & - & 14 \\
\hline Kindar Kheda & 1 & - & - & - & - & 1 \\
\hline Srinagar & 1 & - & - & - & - & 1 \\
\hline Ghumli & - & - & 1 & - & - & 1 \\
\hline Navi Bundar & 1 & - & - & - & - & 1 \\
\hline Somnath & 6 & 2 & 35 & - & - & 43 \\
\hline Mul Dwarka (Kodinar) & 1 & - & - & - & - & 1 \\
\hline Gopnath & - & 1 & -- & - & - & 1 \\
\hline Hatab & - & 4 & - & - & - & 4 \\
\hline Ghogha & 1 & 18 & - & - & - & 19 \\
\hline Mithi Virdi & - & 4 & - & - & - & 4 \\
\hline \multicolumn{7}{|l|}{ Maharashtra } \\
\hline Dabhol & - & 4 & - & - & - & 4 \\
\hline Vijaydurg & 1 & 23 & - & - & - & 24 \\
\hline Sindhudurg & 3 & 5 & - & - & - & 8 \\
\hline Padmagad & - & 1 & - & - & - & 1 \\
\hline Vengurla Rock & - & - & 1 & - & - & 1 \\
\hline \multicolumn{7}{|l|}{ Goa } \\
\hline Baga & - & 1 & - & - & - & 1 \\
\hline Sunchi Reef & - & 1 & 1 & - & - & 2 \\
\hline Grande Island & - & 2 & - & - & - & 2 \\
\hline \multicolumn{7}{|l|}{ Kerala } \\
\hline Kannur & - & 1 & - & - & - & 1 \\
\hline Kollam & - & - & 1 & - & - & 1 \\
\hline \multicolumn{7}{|l|}{ Lakshadweep Island } \\
\hline Minicoy Island & - & 1 & - & - & - & 1 \\
\hline \multicolumn{7}{|l|}{ East coast } \\
\hline \multicolumn{7}{|l|}{ West Bengal } \\
\hline Harinarayanpur & - & - & - & 1 & - & 1 \\
\hline \multicolumn{7}{|l|}{ Odisha } \\
\hline Astaranga & - & - & - & - & 1 & 1 \\
\hline Belkhandi & - & - & - & 1 & - & 1 \\
\hline Manikapatna & - & 1 & - & - & - & 1 \\
\hline Chilika Lake & 4 & - & - & 1 & - & 5 \\
\hline \multicolumn{7}{|l|}{ Andhra Pradesh } \\
\hline Kottapatnam & - & - & - & 1 & - & 1 \\
\hline \multicolumn{7}{|l|}{ Tamil Nadu } \\
\hline Manapad & - & - & - & 5 & - & 5 \\
\hline Kursadi Island & - & 1 & - & - & - & 1 \\
\hline Poomarichan Island & - & 1 & - & - & - & 1 \\
\hline Vedalai & - & 1 & - & - & - & 1 \\
\hline Periapattinam & - & - & - & 1 & - & 1 \\
\hline Threspuram & - & 1 & - & - & - & 1 \\
\hline
\end{tabular}

1993; and the findings of Manikapatna were broadly divided into two periods, namely, from 2nd century BCE to 5th-6th century CE and from 9th to 19th century CE. The excavation findings included Khorasthi inscription, Knobbed ware, Rouletted ware, local pottery, beads, stone and terracotta artefacts and figurines. Coins of the Puri-Kushan period (1st century CE), Rajaraja Chola (985-1016 CE), Sahassamalla of Polonnaruva period, Sri Lanka and Jiaqing Emperor of
Qing Dynasty, China (18th century CE) as well as Chinese porcelain (1368-1644 CE) (Figure 2) belonging to Yuan and Ming dynasties are also recorded ${ }^{9-11}$. The reading order of front four Chinese characters of a Jiaqing Emperor coin is from top to down, and then from right to left. 'Jia Qing Tong Bao', meaning 'The Circulating Treasure of Jiaqing Reign' and on the reverse Manchu alphabet is inscribed on the coin. Probably the coin was issued from Beijing 
(pers. commun.: Ran Zhang and Derek Kennet). Besides the archaeological findings, Abul Fazal (1551-1602 CE) mentioned Manikapatna as salt tax collection centre ${ }^{12}$, and it is also mentioned in the Gujarati maps of 16th and 17 th century and sea manuals of the 18 th century ${ }^{10}$. Many geographical accounts refer to Manikapatna port, whereas Bowery ${ }^{13}$ described Manikapatna along the coast of Gingelly. Archaeological and other evidences indicated that Manikapatna served as port up to late medieval period.

During the recent explorations along the Odisha coast, broken Indo-Arabian and composite stone anchors were discovered at Manikapatna and Kanas on the bank of Chilika Lake (Figure 3). One kellick stone anchor was recovered from the River Devi at Astaranga at 5 to $7 \mathrm{~m}$ water depth. Similarly, one-armed anchor with stone stock and wooden shank, as well as weight stone anchors were recorded along Konark coast and adjoining regions. Apart from the Indo-Arabian stone anchor, fragments of amalaka (notched stone disk), pieces of perforated window, pillar segments, dressed stone blocks and other architectural elements were observed near mosque during explorations at Manikapatna. The residents of Manikapatna informed that these findings were recovered while digging for the construction of a new mausoleum. All these architectural materials belonged to a temple. Moreover, Chinese ceramic sherds (Figure 4) of 13th to 14th century CE were also recovered, and these were produced in Fujian and Zhejiang Provinces of China (pers. commun.: Ran Zhang). Although different types of stone anchors have been recorded during explorations along the Odisha coast, this paper details the IndoArabian stone anchor of Manikapatna along with other findings and their role in the maritime contacts of Mani-

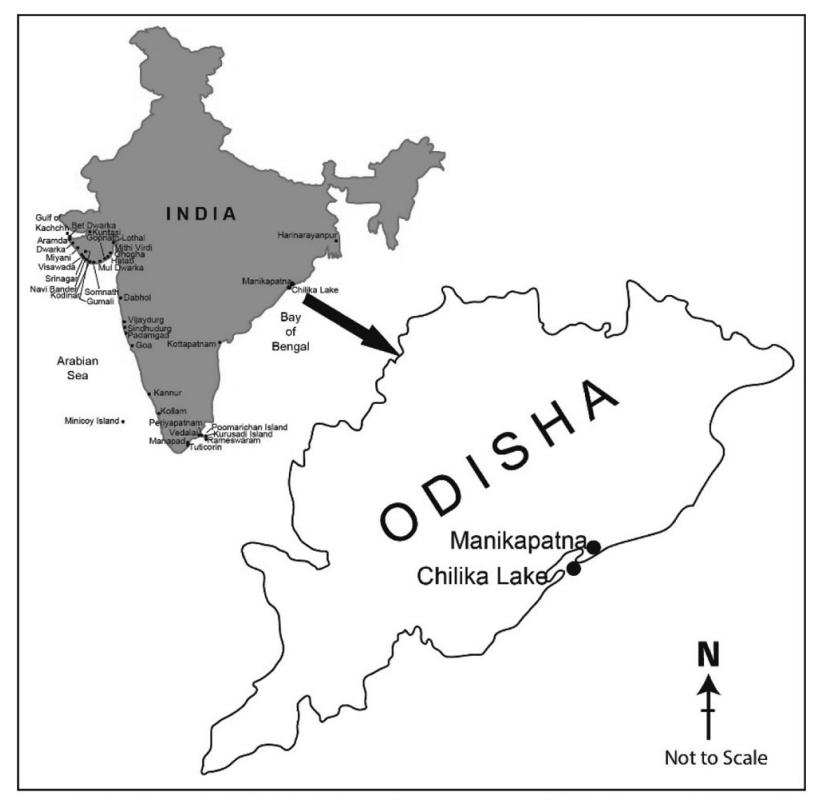

Figure 1. Map showing the stone anchor sites in India. kapatna, and a comparative study is made with other Indo-Arabian stone anchors of India.

\section{Description of the Indo-Arabian stone anchor of Manikapatna}

The Indo-Arabian stone anchor of Manikapatna was a broken one; however, both the lower holes are well intact and well preserved. Proportionately, the lower holes differed in size. One lower hole was filled with sand, and the other hole was empty. The upper portion of the anchor, including the top hole for tying the rope, was missing (Figure 3). The surface of the anchor was neatly chiselled, which was distinct with no noticeable marks or signs on the surface. As the rock was porous, a distinct crack was present on the surface, and a piece of rock had come out from one side of the anchor. Some greenish and reddish patches and white spots were visible on the surface. The upper fragment of the anchor was not found in the vicinity despite extensive search in the area. Therefore, it becomes essential to comprehend how, why and by whom the anchor (complete or broken) was brought to Manikapatna. Because of sedimentation, formation of sandbar and closure of the mouth of Chilika Lake, sea going vessels carrying Indo-Arabian stone anchors abstained from entering into the lake. Besides, the traditional crafts which now ply in the lake either use weight stones as anchors or tie the boat with a pole, but certainly not Indo-Arabian stone anchors.

\section{Discussion}

Maritime archaeological investigations along the Indian coast have yielded composite, Indo-Arabian, ring stone, kellick and single hole stone anchors. These stone anchors are categorized following their region and shape. Still, no evidence has so far been recorded in respect of their origin, since their use and introduction in Indian waters. An abundant number of composite stone anchors have been discovered from the Mediterranean Sea ${ }^{14-16}$, which are similar to the anchors found in India. Until now there was no direct evidence suggesting that the composite stone anchors found in Indian waters were introduced by Mediterranean mariners. It could be assumed that composite, ring stone and single hole stone anchors might have originated in India by the Indian mariners. However, these anchors are analogous to the anchors of Mediterranean Sea and other places. The Arab mariners might have introduced the Indo-Arabian stone anchors in India as well as in the Indian Ocean region, as the earliest Indo-Arabian stone anchor of the Indian Ocean region was recovered from the coastal excavations of Siraf port, Iran, datable to the 8 th -11 th century $C E$ (ref. 17). The Arab mariners frequently visited the ports of west coast of India, and subsequently visited the east coast and 


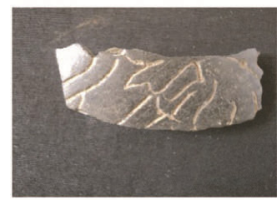

Khorasthi Inscription

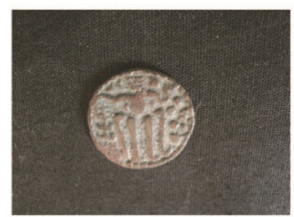

Sri Lankan coin

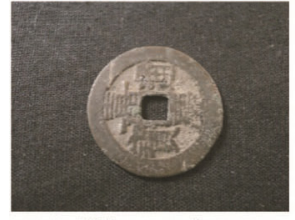

Chinese coin

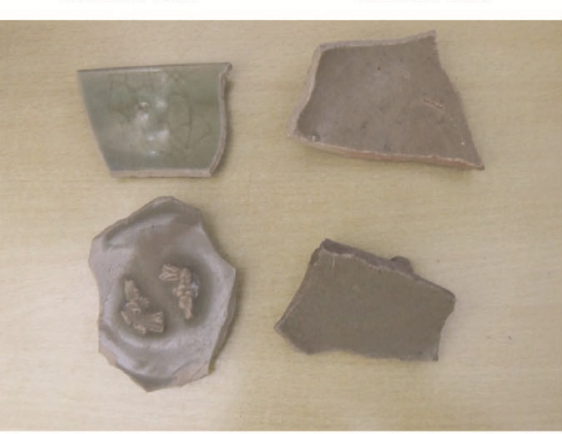

Chinese porcelain

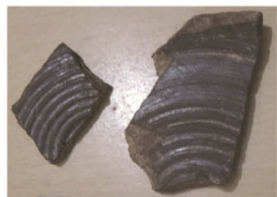

Knobbed ware

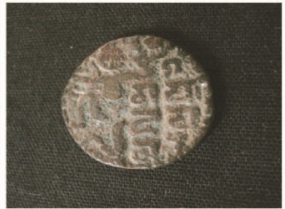

Sri Lankan coin

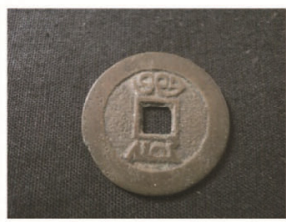

Chinese coin

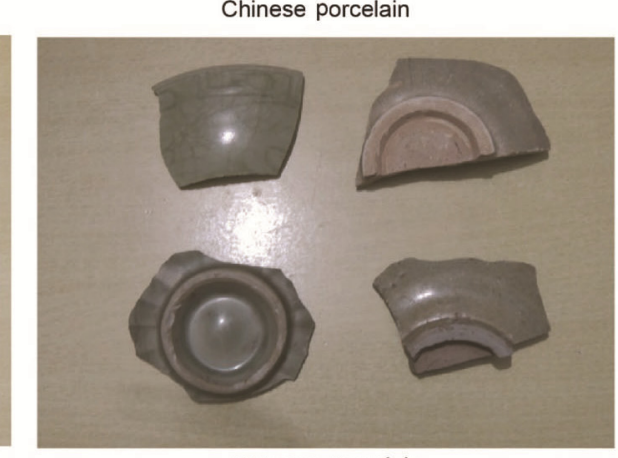

Chinese porcelain

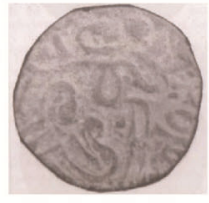

Raja Raja coin

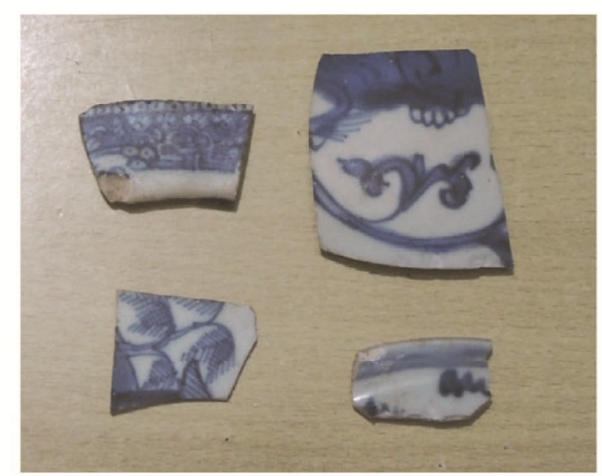

Chinese porcelain

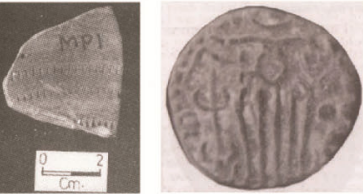

Rouletted ware

Raja Raja coin

Figure 2. Archaeological findings from the excavations of Manikapatna (OIMSEAS).

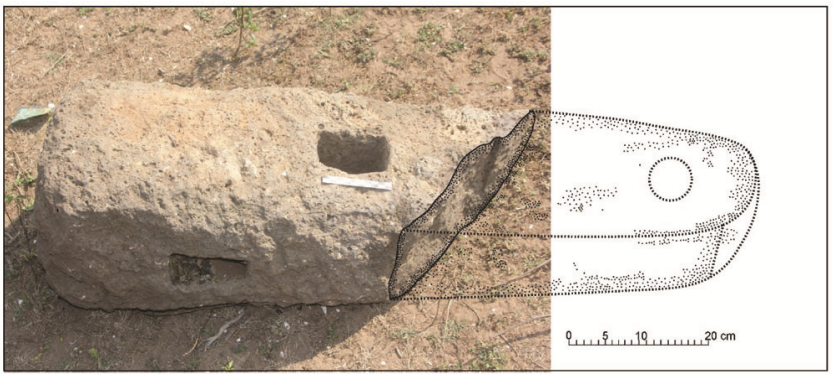

Figure 3. Broken Indo-Arabian type of stone anchor of Manikapatna.

Southeast Asian countries for maritime trade. Suppose Indo-Arabian stone anchors found in India belonged to an archaeological context before 8 th-9th century CE, then, the period and perception of the introduction of IndoArabian stone anchors by the Arab mariners can be researched. The finding of Indo-Arabian stone anchors in the Red Sea ${ }^{18}$, Persian Gulf ${ }^{19}$ and Indian Ocean region indicate Arab mariners' interactions in maritime trade and contacts. These Indo-Arabian stone anchors have also been reported from $\operatorname{Iran}^{17}$, Oman ${ }^{19}$, Sumhuram (Khor Rori),

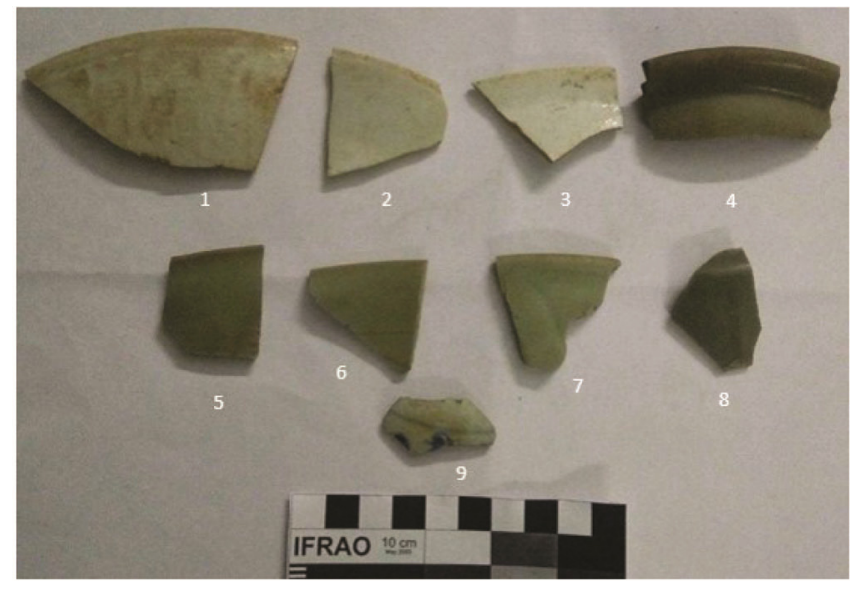

Figure 4. Chinese pottery collected during explorations at Manikapatna.

an ancient south Arabian city ${ }^{20}$, Kenya ${ }^{21}$, Red Sea ${ }^{18}$ and Sri Lanka ${ }^{22}$ as well as east and west coasts of India ${ }^{1}$.

Usually, in Indo-Arabian type stone anchors wooden flukes were secured either in square or rectangular holes found at the lower end facing opposite to each other and 
in the round hole at the apex meant for rope or cable. These pointed wooden flukes protrude on either side of the anchor holes, get into the seabed and hold firmly. Indo-Arabian anchors were able to withstand rocky, coral or sandy seabed. The lower side of these stone anchors were broader than the upper side and tapered upwards. Since the lower side of these anchors are broader and heavier, they provide sturdier, better grip and possibilities of drifting become minimal. The shape and other features of Indo-Arabian stone anchors differ from composite, ring stone, single hole as well as kellick stone anchors.

In addition to their use as anchors, there have been instances of their reuse as lintels and doorsill along the west coast of India. The first reuse of Indo-Arabian and composite stone anchors came in to limelight at Sindhudurg fort ${ }^{23}$, Malwan, as mooring bits, pavement and doorsill at the entrance of the fort. Another anchor was used as a lintel at the entrance of Padmagad fort ${ }^{23}$, Malwan, Maharashtra. Similarly, eight Indo-Arabian stone anchors have been used as lintel in the second fortification wall of the Vijaydurg fort ${ }^{24}$, Maharashtra. One more IndoArabian stone anchor was used as lintel at the Jama Mosque of Funhilol of Minicoy Island, Lakshadweep, but was removed during mosque's renovation, and it is now lying inside the compound ${ }^{25}$. The discovery of Indo-Arabian anchors from adjacent areas of Funhilol Mosque ${ }^{25}$, like Hydross Palli Mosque, near Kannur beach, Kerala ${ }^{26}$, Vedalai Mosque, Mandapam, Tamil $\mathrm{Nadu}^{27}$, and the anchor discussed here from the mosque of Manikapatna, suggest their affinity with the Arab mariners for centuries together. Moreover, there is a Persian inscription ${ }^{28}$ by Mohammed Kamal, found on the wall of the Manikapatna mosque constructed during the time of Mughal Emperor Shah Alam II in 1193 Hizra (1779 CE). Among the several muslim pir tombs of Odisha, Manikapatna ${ }^{29}$ too has one such tomb.

The stone anchor of Manikapatna might have been brought by Arab mariner(s) to display at the mosque as a symbol of passion, but it was discarded once it was broken. However, this is just an assumption, and so other prospects cannot be ignored. Since the initiation of the recording of stone anchors in India, more Indo-Arabian and ring stone anchors have been discovered than composite and single hole stone anchors (Table 1). Nevertheless, it appears that some of these types of stone anchors are being used concurrently in Indian waters. The previous studies suggest that composite stone anchors were mostly used along the Gujarat coast ${ }^{30-32}$ for some period of time, and their findings beyond Gujarat was minimal except the one found in Vijaydurg ${ }^{33}$, but not beyond this, as well as along the east coast of India. Another interesting aspect is that more stone anchors have been discovered than the shipwrecks so far explored in India and other parts of the world.

Stone anchors were generally made of local rocks, but earlier studies showed that majority of Indo-Arabian anc- hors were made of igneous rocks namely basalt, granodiorite, serpentinite and dolerite, no doubt, some were also made of calcareous sandstone and limestone ${ }^{34,35}$. The Indo-Arabian anchor of Manikapatna is made of basalt. Stone anchors appear identical, but, inevitably, they differ mineralogically in their composition. In comparison with the number of anchors discovered from different parts of the world, reviews on their provenance studies have been limited. In order to ascertain the source of rock of stone anchors, it is essential to understand the rock types as well as their exposures along the coastline.

\section{Conclusion}

The finding of the lone Indo-Arabian anchor has great significance in the maritime history of the eastern littoral. Although several ports existed along the Odisha coast, limited stone anchors have been discovered, and the IndoArabian anchor of Manikapatna is exceptional. None of the ports of Odisha has a long history like that of Manikapatna, which continued from the early historical period to 18 th century CE. Even there were few ports along the east coast of India, which continued for such a long period. It has further been observed that the number of stone anchors reported from the east coast of India is much less than from the west coast of India. Additionally, the discovery of stone anchors in the adjoining area of mosques suggests the affinity of Arab mariners with the Indo-Arabian anchors and the finding of the identical stone anchors infers maritime contacts among the regions.

Despite the advancement of tools and technology in the field of shipping, shipbuilding, i.e. wood to steel and sail to steam, and stellar to satellite navigation, traditional fishermen continued to use stone anchors until the recent period. This suggests how much people were certain about their traditional inventions, imbibed with traditional knowledge. Moreover, no change was seen in the shape of the anchors for centuries together. Therefore, it is crucial to understand the indigenous knowledge, and this brings the attention of maritime archaeologists to study the stone anchors.

1. Tripati, S., Stone anchors of India: Findings, Classification and Significance. In Proceedings of the 2nd Asia-Pacific Regional Conference on Underwater Cultural Heritage (eds Tilburg, H. V. et al.), Honolulu, Hawaii, 2014, vol. 2, pp. 973-986.

2. Ratnagar, S., Trading Encounters from the Euphrates to the Indus in the Bronze Age, Oxford University Press, New Delhi, 2004.

3. Rao, S. R., Lothal - A Harappan Port Town, Part I, Archaeological Survey of India, New Delhi, 1979.

4. Rao, S. R., Shipping and maritime trade of the Indus people. Expedition, 1965, 7(3), 30-37.

5. Dhavalikar, M. K., Raval, M. R. and Chitalwala, Y. M., KuntasiA Harappan Emporium on the West Coast, Post Graduate Research Institute, Deccan College, Pune, 1996. 
6. Singh, J., Prachin Utkal (Odia), Odisha Shahitya Academy, Bhubaneswar, 1982, 2.

7. Tripati, S., Maritime Archaeology: Historical Descriptions of the Seafarings of the Kalingas, Kaveri Books, New Delhi, 2000.

8. Dash, R. N., Boat Building in Odisha. In Maritime Activities and Trade in Odisha (ed. Sahoo, P.), Odisha State Archives, Bhubaneswar, 1996, pp. 13-21.

9. Pradhan, D., Manikapatna excavations (1989-1993): cultural affinities of Southeast Asia through archaeological evidences. In Kalinga-Indonesian Cultural Relations (ed. Behera, K. S.), OIMSEAS, Bhubaneswar, 2007, pp. 71-95.

10. Behera, K. S. (ed.), Maritime activities of Orissa. In Maritime Heritage of India, Aryan Books International, New Delhi, 1999, pp. 162-171.

11. Satyamurthy, T., Two copper coins from Manikapatna-An ancient sea port of Orissa. In Studies in South Indian Coins, 2003, vol. 13 , pp. $38-41$.

12. Raut, L. N., Socio Economic Life in Medieval Orissa, Punthi Pustak, Calcutta, 1998.

13. Bowery, T., A Geographical Account of Countries Round the Bay of Bengal 1669-1679, Asian Educational Services, New Delhi, 1993.

14. Toth, J. A., Composite stone anchors in the ancient Mediterranean (Typology, chronology and their role in the reconstruction of ancient trade) A Proposal. Acta Archaeol. Acad. Sci. Hungaricae, 2002, vol. 53, pp. 85-118.

15. Noureddine, I., Stone anchors off the shore at Byblos. BAAL, 2016, 16, 293-308.

16. Zazzaro, C. C. and Abdelmaguid, M. M., Ancient Egyptian anchors: new results from Wadi Gawasis. Abgadiyat, 2016, 11, 160 167.

17. Whitehouse, D., Excavations at Siraf, Second interim report. Iran, 1970, 8, 1-17.

18. Raban, A., Medieval anchors from the Red Sea. Int. J. Naut. Archaeol., 1990, 19, 299-306.

19. Vosmer, T., Indo-Arabian stone anchors in the western Indian Ocean and Arabian Sea. Arab. Archaeol. Epigr., 1999, 10, 248 263.

20. Avanzini, A. (ed.), A Port in Arabia between Rome and the Indian Ocean, 3rd C. BC-5th C. AD: Khor Rori Report 2, Rome, Arabia Antica, 2008

21. Bita, C. and Tripati, S., Stone anchors from Mombasa, Kenya: evidence of maritime contacts with Indian Ocean countries. Bull. Aust. Inst. Marit. Archaeol., 2015, 39, 84-91.

22. Souter, C., Stone anchors near Black Fort, Galle, Sri Lanka. Int. J. Naut. Archaeol., 1998, 27, 331-342.

23. Tripati, S. and Gaur, A. S., Stone anchors from Sindhudurg Fort on the west coast of India. Int. J. Naut. Archaeol., 1997, 26(1), 51-57.

24. Tripati, S., Gaur, A. S., Sundaresh and Bandodker, S. N., Historical period Stone anchors from Vijaydurg on the west coast of India. Bull. Aust. Inst. Marit. Archaeol., 1998, 22, 1-8.
25. Tripati, S., Stone anchors from Minicoy Island, Lakshadweep, India. Int. J. Naut. Archaeol., 2009, 38, 406-412.

26. Tripati, S., Manikfan, A. and Mohamed, M., An Indo-Arabian type of stone anchor from Kannur, Kerala, West Coast of India. Int. J. Naut. Archaeol., 2005, 24, 131-137.

27. Athiyaman, N., Ancient and medieval ports of the Gulf of Mannar Coast, East coast India and their maritime connections across Indian Ocean Countries. In Proceedings of the 2nd Asia-Pacific Regional Conference on Underwater Cultural Heritage (eds Tilburg, H. V. et al.), Honolulu, Hawaii, 2014, vol. 2, pp. 923-936.

28. Tripati, S. and Vora, K. H., Maritime heritage in and around Chilika Lake, Orissa: geological evidences for its decline. Curr. Sci., 2005, 88, 1175-1181.

29. Ray, B. C., Orissa Under the Mughals, Punthi Pustak, Calcutta, 1981.

30. Gaur, A. S., Sundaresh and Vora, K. H., Underwater Archaeology of Dwarka and Somnath, Aryan Books International, New Delhi, 2008.

31. Gaur, A. S., Sundaresh and Vora, K. H., Archaeology of Bet Dwarka Island: An Excavation Report, Aryan Books International, New Delhi, 2005.

32. Gaur, A. S. and Sundaresh, Maritime Archaeology Around Porbandar, Aryan Books International, New Delhi, 2013.

33. Tripati, S., Saxena, M. K., Sundaresh, Gudigar, P. and Bandodkar, S. N., Marine archaeological exploration and excavation of Vijaydurg - a naval base of the Maratha period, Maharashtra, on the west coast of India. Int. J. Naut. Archaeol., 1998, 27(1), 51-63.

34. Tripati, S., Mudholkar, A., Vora, K. H., Rao, B. R., Gaur, A. S. and Sundaresh, Geochemical and mineralogical analysis of stone anchors from west coast of India: provenance study using thin sections, XRF and SEM-EDS. J. Archaeol. Sci., 2010, 37, 19992009.

35. Iyer, S. D., Vora, K. H. and Gaur, A. S., Geological significance of stone anchors from Dwarka waters, Gujarat, India. In Glimpses of Marine Archaeology in India (eds Gaur, A. S. and Vora, K. H.), Society for Marine Archaeology, National Institute of Oceanography, Goa, 2006, pp. 78-81.

ACKNOWLEDGEMENTS. I am grateful to the Director, CSIRNational Institute of Oceanography for encouragement and support and indebted to Drs Anam Behera of Utkal University for sharing information on the anchor, and Ran Zhang and Derek Kennet, Durham University, UK, for identifying the Chinese ceramic sherds and coins of Manikapatna. The support of Shri Mokadar Mohammed of Manikapatna during the fieldwork of Manikapatna is appreciated. I am indebted to anonymous reviewers for their valuable suggestions on the manuscript. Thanks are also due to Shri Rudra Prasad Behera and Sujal Bandodkar for figures. This is NIO contribution no. 6688 .

Received 28 November 2019; revised accepted 28 December 2020 doi: $10.18520 / \mathrm{cs} / \mathrm{v} 120 / \mathrm{i} 7 / 1211-1216$ 